\title{
CULTURAL PROBLEMS OF TURKEY, BY EKREM AKURGAL (KIRMIZI KEDI, 2018)
}

\author{
SEDEN EREN ${ }^{l}$
}

This book, originally entitled Türkiye'nin Kültür Sorunları, is an anthology of articles written by Ordinarius Professor Doctor Ekrem Akurgal from 1942 until 1998, edited for publishing by Burak Kuru in 2018. Prof. Akurgal is a distinguished and reputable academic well known for his archaeological research, acknowledged by honorary doctorates and awards and memberships in science academies across Europe. Prof. Akurgal was the founder of classical archeology as an academic science in Turkey and a lecturer in Turkey and abroad. In 1934, the Turkish Republic adapted the "Surname Law," based on which all citizens had to choose a fixed and hereditable last name. The author's devotion to history and archeology can be seen in his choice of "Akurgal," meaning "big water land" in the Sumerian language, as a last name.

Prof. Akurgal served as a lecturer in various archaeological departments in Turkey and many professors today used to be his student. Therefore, he is referred to as the "Professors' professor." Besides lecturing at Turkish and foreign universities, Prof. Akurgal led countless archaeological excavations. His main area of research was the Aegean region. He undertook excavations in Phokaia (Foça), Erythrai (Ildırı), Smyrna (Bayraklı) and Pitane (Çandarlı), and continued his excavations and work until his death in 2002. Based on his research he published various books in different languages on ancient Greek, Hatti, Hittite, and old Anatolian civilizations.

$\mathrm{He}$ is considered to be an "Anatolianist." The latter offspring of cultural nationalism was first formulated in 1918 by Halide Edip Adıvar, who was one of the first female novelists during the dusk of the Ottoman Empire and who considered Frank Tachau's theory of cultural linkage based on the geographical area between ancient civilizations in Anatolia and the current-day Turkish Republic. The Turkish state and culture have natural boundaries within which

1 Seden Eren is a Ph.D. candidate at the Institute of Sociology and Social Policy at Corvinus University of Budapest; e-mail: sseren1@yahoo.ca 
may be identified similarities between the ancient residents of Anatolia as Hattis, Hittite, Greeks and Turkish culture that bloomed on Anatolian soil and became the basis of Turkish identity. Prof. Akurgal's views resonate with the culturebuilding theory promulgated by Anthony Smith in his book National Identity in 1991, whereby a state's current culture is inherited, mixed, and evolves based on geographical "sameness" and historical "others."

In this book, the author summarizes his almost sixty years of experience with history and archeology. He does not simply offer facts from a historical perspective, but also attempts to connect current (n.b. current at the time of writing) events to historical events and reasonable scenarios. He describes Turkish society today and links it to historical "yesterday" and suggests scenarios for "tomorrow." Prof. Akurgal evaluates the cultural problems of Turkey and provides a list of suggestions about what to do for a better future. Additionally, he drills deeper into ancient history and seeks to raise the reader's attention to the importance and influence of early Anatolian civilizations on European history (the influence of Hattis, Hittite, Urartu and other Anatolian and Mesopotamian civilizations that can still be felt over the centuries, particularly in Math, Astrology, Law and Agriculture).

The author gathers his long-term research in this book with an explanation about how important it is to publish the results of research in order to deal with local and international issues. He argues that the impressions and experiences obtained from this research can help people to achieve compromise, which can lead to conscious and decisive solutions to the problems of societies. As part of his perspective about interconnecting cultures, Prof Akurgal claims that there is no society in the world that has created their own culture, architecture, or sculpture without being influenced by other cultures and cultural elements. Shaping the culture of a nation can happen organically (via invasions, assimilation) or be driven by elites (diplomacy and trade).

In the first chapter, the author discusses whether Turkey is cultured. Prof. Akurgal associates culture with art and access to it. The basis for the comparison is established using an appraisal of the number of concerts, theaters, art galleries, exhibitions and bookstores in Turkey and Western-style states. He attempts to answer this question by explaining three significant key points: the origins of Turkish culture and the civilizations which affected Turkey, the sources feeding Turkish culture today, and the tradition of Turkish culture. The author claims that no culture comes from nothing. Each new stream carries the influences of earlier currents and their environment.

A nation's culture can be developed via the melding of state power, intellectual work, enthusiasm, scientific and cultural curiosity, and effort. In this context, wherever the influences come from, each community creates a unique national 
culture to the extent that it works and endeavors. Prof. Akurgal believes that in order to understand our current culture we need to know about the influences of different cultures, such as that of the Greeks, Arabs, Persians and Romans. Therefore, each culture internalizes the components it receives and reshapes them based on their own values. This cycle can be observed in Turkish culture as well. Furthermore, modern Turkish culture is shaped by inherited cultural elements of the Urartian, Hittite, and Lycian civilizations and many others who used to live in the same geographical area. While discussing cultural problems, the author also points out contemporary issues, such as historical monument trafficking, smuggling, and care for abandoned historical ruins.

In the second chapter, the author emphasizes why we should care for and pay attention to art, especially to architecture. He claims that, starting from the Seljuk and Ottoman Empires, architecture has been the most successful cultural branch of the Turks. Prof. Akurgal argues that Turks do not support their own art as much as they should, and that they have acted indifferently towards it. He points out that there is not enough research or publications about Turkish art by Turkish authors in Turkey. On the other hand, even France, Germany and England have made more contributions in this regard. For this reason, he attempts to draw the attention of Turkish intellectuals to caring for their own art.

The third chapter is called "Lessons to learn from history." The author evaluates the position of the Turks among world civilizations. He claims that the most precious asset of a nation is its civilizational work that is improved throughout human history. It is argued that every nation culturally advances in terms of the proportion of the greatness and importance of poets, composers, philosophers, scientists, architects, painters and sculptors who are brought up by that nation. Thus, national heritage consists of the work of these artists, the accumulation of their work, and how this reaches the next generations. Besides being a part of national heritage, these works represent the common civilization products of all humanity. For instance, the remains of civilizations that lived in Anatolia before the arrival of Turks to Anatolia are cultural treasures of the whole world.

Prof. Akurgal attempts to assess whether Turks are a part of Eastern or Western culture. The definition of Eastern (paternalistic, collectivistic) culture versus Western (individualistic, rationalistic) culture can be viewed as a combination of Geert Hofstede's theory, named "Culture's Consequences: Comparing Values, Behaviors, Institutions, and Organizations Across Nations." With this work about cultural dimensions, Hofstede defines the influence of a society's culture on the values of its members, and explains how these values connect to behavior.

For instance, according to Hofstede, "power distance" is the amount to which the less powerful members of organizations within a country anticipate and 
accept that power is deployed unequally. Turkey's score shows that the country is dependent and hierarchical, and power is centralized. Decisions are made by patriarchal elites. Father figures lead society like the heads of a big family. Furthermore, the dimension "Individualism vs. Collectivism" explains the level of interdependence a society sustains within its members. Individualist societies look after themselves. However, collectivist societies contain groups that have unquestioning loyalty. In terms of this cultural dimension, Turkey is a collectivist society. As a collectivist country, instead of "I," "we" is important. Therefore, belonging to a group is of significant value.

On the other hand, Prof. Akurgal does not categorize his views on the subject in order to keep his ideas on a conversational level rather than an academic one. He investigates the topic from a historical perspective and first points out the main difference between East and West throughout history. Historically, the significant difference between the West and East has been "freedom," even though freedom found a suitable environment in the East during the times of Sumerians, Hittites, Phoenicians, Abbasids and Selcuks. Great and powerful theocratic and absolutist states started to emerge with the Akats in $2500 \mathrm{BC}$. With this, the attempts at liberty of the eastern world left the hands of the people. The state came to monopolize and govern these attempts and, through this, "independent" definition of society disappeared. Due to a lack of competition, the movement towards freedom lost its dynamism, and the possibilities for development rapidly faded. In Western societies, freedom was limited during certain periods and regions, especially in theocratic and absolutist states. However, despite the periodic interruptions, the concept of freedom and liberty have been sustained in the West.

The author suggests that the question whether to define Turkey as an Eastern or Western culture is of significant importance even today (please note that the author was writing about the second half of the twentieth century). Primarily, he evaluates the two different options that should be considered in order to answer this question. The first alternative is to learn about technology from the West and preserve the essence of society (patriarchal family values, traditional means of human interaction, beliefs, superstitions, and Islamic heritage). The second alternative is radical Westernization, the same process which was started by Mustafa Kemal Atatürk in 1923 that resulted in the revolutionary adaptation of all Western values and the unloading of the archaic values that had prevented Turkey from shining. Furthermore, he explains whether it is possible to perform a synthesis of East and West, whence he investigates the historical attempt at Eastern and Western synthesis by Alexander the Great.

The fourth chapter is about the importance of Anatolian civilizations in world history. Prof. Akurgal investigates Anatolia's ethnic structure. Based on his 
research, eight thousand years ago Anatolia was the region which hosted the world's top cities, lasting two or three thousand years, with settlements like Çayönü, Hacılar, and Çatalhöyük. Anatolia has been the world's cultural leader twice in history. Its first period of leadership was in the New Stone Age (80005000 B.C.). The inhabitants of this region were the oldest known farmers in Anatolia. According to findings from excavations, they knew how to grow wheat, and how to harvest and grind it. They engaged in animal husbandry, including taming goats and dogs, in addition to agricultural work.

The following period was that of the Natural philosophers (650-450 B.C.). In this era, Aegean inhabitants took control of world trade, becoming the most successful traders in the world. Large houses, roads, temples, and monuments were built. Competition started with trade but led to free thought. Natural philosophers from Miletus left religious concerns and mythological beliefs behind them and directed their attention to rational and realistic thinking. They transformed the knowledge received from Mesopotamia and Egypt into science. These philosophers established the first principles of mathematics, astronomy, geometry, and medicine. For instance, Thales of Miletus (625-545 B.C.) calculated the solar eclipse of May 28, 585 BC in advance. Anaximander (610-545) drew a map of the lands and seas that were known at the time.

In this chapter, Prof. Akurgal also provides us with a summary of all major ethnic groups and civilizations (for example, Hurrians, Lydians, Romans...) that shaped the culture of Anatolia from the earliest states until the present day. He starts with the Hattie (2500-2000 B.C.) civilization, which did not leave enough of a footprint to permit an assessment of their language or their names, and continues until the Turkish Republic (1923-). In this context, each civilization has affected the other. According to his historical research and findings, around four thousand years ago people of European origin started to migrate to Anatolia and became the dominant ethnic group until the arrival of Turks in 1071 AD.

Prof. Akurgal claims that during the Hittite era (1700-1100 B.C.) there were women's rights, a nobles' assembly, and a system of constitutional monarchy in Anatolia. In the following years, the Hellenistic Age (1050-30 B.C.), human rights, freedom of thought, and scientific studies were common. However, these features began to decline in the Roman- (30 B.C.- 395 A.C.), Byzantine- (3951453) and Ottoman (1299-1922) periods. Although they fused with European communities, the Ottomans could not adopt a European world view, meaning adapting to renaissance thinking, nurturing the natural sciences, and organically becoming exporters of scientific developments around the globe.

In spite of some developments in the period of Mehmet II (1444-1446 and 1451-1481), after the defeat of Vienna in 1683 Turks became further separated and isolated from Western culture and adapted more Islamic elements. With 
the period of the Republic of Turkey, the unity of culture was completed in Anatolia. Turkey has considered Anatolian history to be their national heritage, and cultural unity has been achieved. Accordingly, while renaissance, reform, and enlightenment movements took centuries in Europe, they took place in a short time in Turkey.

The author's dream of discovering the past to help his country build a great, Western-style state makes him a visionary whose influence stretches beyond archeology to all social studies. The author believed, at the time of writing in the 1950-1990s, that Turkey was on a promising track in terms of adopting Western culture and values, and becoming a secular state driven by rational decisions, where lessons from the past would not be forgotten.

I would recommend reading this book in order to get to know about the work of the man who created the foundation of modern Turkish archeology, and to understand Prof. Akurgal's views about historical, social, and cultural aspects of Anatolian civilization and their presumable impact on the Turkish Republic. Prof Akurgal's passion of connecting civilizations that existed in the same place but in different eras represents a unique view of how human history can be viewed from higher ground. The cultural elements, and how they change, are like anchored rocks that are polished by the river of civilizations flowing over the centuries. 